\title{
Business Risks and the Level of Entrepreneurial Optimism among SME in the Czech and Slovak Republic
}

\author{
- Belás Jaroslav, Macháček Jiř, Bartoš Premysl, Hlawiczka Roman, \\ Hudáková Mária
}

\begin{abstract}
The aim of this article is to define and compare current trends within business risks among small and medium enterprises in selected regions of the Czech Republic and Slovakia in the context of entrepreneurial optimism. In 2013, the research on entrepreneurs' opinions in the Zlín Region (Czech Republic) and Žilina Region (Slovakia) was conducted. These regions have similar economic parameters and are separated by only a few miles.

According to our research, it can be stated that during the period of financial crisis, the situation in the SME business deteriorated significantly with declining performance and profitability of Czech and Slovak small and medium enterprises. The most important business risk is still market risk, followed by financial and eventually personal risk. Our research showed that the profitability of Czech and Slovak small and medium enterprises decreased by $15 \%$. Despite these facts, the level of entrepreneurial optimism among SME in the selected regions of the Czech Republic and Slovakia is very high.
\end{abstract}

Keywords: small and medium enterprises, business risks, market risk, financial risk, personal risk, commercial banks, entrepreneurial optimism

JEL Classification: L 26, O 16, G 32

\section{INTRODUCTION}

Basic prerequisite for successful management and development of all businesses is a favorable business environment. It is represented by the environment, in which economic competition is supported and protected by state, which creates clear and stable conditions and ensures their compliance by all market participants, while minimizing administrative barriers towards entrepreneurs.

The issue of business risks of small and medium enterprises (SME) represents now current area of theoretical research and practical applications.

Financial crisis and gradual recovery of economies in the European Economic Community brought deterioration of the business environment.

Presumably, business risks have been increased due to turbulences in the economic system. Small and medium enterprises operate in more challenging economic environment, respectively, many of them struggling with their own survival. It is evident that all these risks are transformed to the financial management of enterprises. 
In the economy system, there are significant concerns as to what banks' practices will be occurred in relation to the loan financial of business community. Current signals confirm that banks in the Czech Republic and Slovakia respond to their clients by more stringent requirements. Therefore it can be occurred very unfavorable situation from the perspective of companies, because this situation restricts the business community in relation to financing by bank instruments. (Geršl \& Jakubík, 2012)

Financial crisis changed the view of risk management in small and medium enterprises (SME) in European countries as well as in Slovakia. On the basis of processed and published studies, the most common failures during the financial crisis, which could substantially affect company's ability to survive during the crisis from the perspective of business management in Slovakia, are as follows: bad management of cash flow and poor management of financial risks, ie. the absence of early warning from financial manager. (Krištofík, 2010)

In this article, current trends in the area of business risks of small and medium-sized enterprises (SME) in Zlin region (Czech Republic) and Žilina region (Slovakia) is examined. One part of this article is representing also research of entrepreneurial optimism. These regions have similar economic parameters and are separated by just a few miles away.

\section{THEORETICAL ASPECTS OF SME BUSINESS}

SMEs have become an increasingly important component of economic development which represents a substantial proportion of the national economies all around the world (Karpak \& Topcu, 2010). In this context, Henderson \& Weiler (2010) state that SMEs can be defined as the major engine of economic growth.

European Commission (2011, p 4) indicate that "source of lifeblood" of the European Economic Community is 23 million European small and medium enterprises that represent more than 98

$\%$ of the business community. They provide two-thirds of total employment contracts in the private sector and in last five years they created approximately $80 \%$ of new job opportunities.

SME play important role also in the economic system of the Czech and Slovak Republic. For example, share of SMEs in total number of active enterprises in the Czech Republic in 2012 was $99,86 \%$. Share of added value in 2012 was $53,81 \%$. Share of SMEs' employees in total employment in business sector in the Czech Republic in 2012 was 59,43\%. In the Slovakia, share of SMEs in total number of active enterprises was $99,2 \%$, in total employment was $72,2 \%$. Share of added value was 55,6 \% and share of SME in profit before taxes was 51,6\%.

For SMEs, entrepreneurial orientation represents also important role. Soininen, Martikainen, Puumalainen \& Kyläheiko (2012) consider innovativeness, risk-taking and proactivity as the essential characteristics of entrepreneurial orientation. Results of their study do not support the assumption that entrepreneurial orientation is positively related to the profitability of small firms. On the other hand, there is a positive relationship between the entrepreneurial orientation of the firm and the firm's rate of growth. Authors state that firms with higher risk-taking profile end up to the higher level of actual measured profitability. According to Eggers, Kraus, Hughes, Laraway \& Snycerski (2013), to drive firm growth, the firm will need to deploy a strategy centered on entrepreneurial orientation or else risk stagnation. 
Avlonitis \& Salavat (2007) indicate that active entrepreneurs unlike passive entrepreneurs adopt a more aggressive orientation characterized by willingness to undertake action of high risk and before that of competition. Nonetheless, proactiveness contrary to risk-taking is found to be an important contributor to the performance of new products introduced by both groups.

Keh, Nguyen \& Ng (2007) investigated entrepreneurial orientation and marketing information on the performance of SMEs and indicate that entrepreneurial orientation plays an important role in enhancing firm performance. Information utilization has positive impact on firm performance, and there is a positive relationship between utilization to make marketing decisions and subsequent firm performance.

SMEs are exposed to many risks. According to Polách, Drábek, Merková \& Polách (2012) and Pavelková \& Knápková (2005), risk represents as a kind of uncertainty where it is possible to quantify the probability of different outcomes. Risk represents a danger where achieved company's results are different from the anticipated ones (it is called the measurable deviation).

According to Fetisovová, Vlachynský \& Sirotka (2004) and Riziká podnikania (2013), among the basic business risks of SME it can be included limited access to loans, small capital strength, increased competition, high tax burden, low level of managerial skills, low level of diversification, administrative complexity, risk of failure, relationship between work and private life.

Particularly important issue of SME is financial gap because many of these companies have very limited access to external financial resources. Even before the economic downturn, small business had some troubles with an availability of financial funds which are necessary for growth and innovation. Due to the financial crisis, banks are even less willing to lend to business sector which lead to further exacerbated problems to which facing companies. (Evropská komise, 2011)

In this context, Dierkes, Erner, Langer \& Norden (2013) state that companies in small and medium sector are smaller, more informationally opaque, riskier, and more dependent on trade credit and bank loans. According to Canales \& Nanda (2012) small businesses, and particularly young small businesses, have little internal cash flow to finance their operations and are also associated with significant asymmetric information.

According to Majková-Sobeková (2012), high risk of SME is based on high debt ratio and limited ability to guarantee. According to this fact, obtaining commercial loans is for such companies problematic. In this context, Di Giuli, Caselli \& Gatti (2011) reported that credit availability is very important element for development of small and medium enterprises.

Neuberger \& Räthke (2009) analyzed SME loan financing. According to authors, microenterprises are especially prone to incorrect selection and moral hazard and therefore their access to loan is limited. Small firms are characterized by higher information asymmetry and by credit risk. This opinion was confirmed also by Kirschenbaum \& Norden (2012) who reported that information asymmetry and bargaining power are especially important in small business lending because small firms are informationally opaque and bank-dependent.

Moro \& Fink (2012) state that banks play an essential role in companies' financing, especially in SME sector because they have more difficulty accessing equity capital markets. The process used 
by banks to decide whether and how much to lend relies on different lending technologies and banks usually tend to use more than one technology at a time.

In the document of Európska komisia (2006) is stated that internal rating of SME debt is considered as the most important quantitative factor by $75 \%$ of total number of large and mediumsized banks in the survey of McKinsey \& Company. 50\% of banks give equal importance to indicators such as liquidity and profitability. From the wide range of possible qualitative factors, around $50 \%$ of medium and large banks attach high or very high importance to the quality management of SME, followed by other factors such as: market situation of SME and their legal form. According to this document, qualitative factors have greater impact on the rating in the case of larger SMEs and larger loans. In the case of start-ups companies, weights of these factors represent $60 \%$ on the overall rating. In the case of companies with sufficient long business history (minimum 2 years), weights of qualitative factors is significantly lower and represents an average of $20-30 \%$.

In this article, current trends in business risks of small and medium-sized companies (SMEs) in selected regions of the Czech Republic and Slovakia is examined. In this article also opinions of entrepreneurs on the financial risk management in the Czech Republic and Slovakia have been investigated. One part of this article is representing also the research of entrepreneurial optimism.

\section{RESEARCH OBJECTIVE AND METHODOLOGY}

Aim of the article is to define and compare current trends in the area of business risks and business optimism of small and medium enterprises (SMEs) in selected regions of the Czech Republic and Slovakia.

The research of fundamental determinants of financial stability of SMEs has been conducted in 2013 through questionnaire survey in selected regions of the Czech Republic and Slovakia. Data was obtained from 180 SMEs in Zlin region and from 164 SMEs Žilina region and provided by their owners.

Zlin region has an area of $3964 \mathrm{~km}^{2}$, has about 600000 inhabitants, GDP per capita is around $€$ 11720 , unemployment in 2012 was about $8 \%$.

Žilina region has an area of $6800 \mathrm{~km}^{2}$ and has about 700000 inhabitants. Population density represents 102 inhabitants per $\mathrm{km} 2$. Unemployment in 2011 was raised to 11,91\% and GDP per capita per person was $€ 10794$ in 2011.

Within our research, the largest share of SME, which do trade activities (35\%), manufacturing activities $(29 \%)$, construction activities (12\%), transport activities (4\%), agricultural activities (3\%), was detected in Zlin region. The remaining share of SME represents companies which do business in other sectors.

In Žilina region, the structure of companies was as follows: manufacturing companies (17\%), trade companies $(21 \%)$, construction companies (17\%), transport companies $(6 \%)$ and agricultural companies $(1 \%)$. The largest share of SME represented companies which do business in other sectors $(38 \%)$. 
From the total number of 180 surveyed companies in Zlin region, $70 \%$ of them do businesses more than 10 years, $21 \%$ do businesses from 10 to 5 years and $9 \%$ do businesses from 5 to 1 year.

Therefore it can be concluded that our survey contains fairly experienced entrepreneurs. Size structure of firms was as follows: $58 \%$ represents micro enterprises, $31 \%$ were small enterprises and $11 \%$ were medium-sized enterprises.

In Žilina region, 164 of surveyed firms do business more than 10 years, 38\% represents firms which do their businesses from 10 to 5 years and $30 \%$ of surveyed companies do businesses from 5 to 1 year. For Žilina region, it can be stated that companies were equally distributed from the perspective of length of business. $66 \%$ was represented by micro enterprises, $20 \%$ were small companies and $14 \%$ were medium-sized enterprises.

In this research, following four hypotheses through estimation methods has been set:

H1. Nowadays, the most significant business risk for SME is represented by market risk. Average value of market risks is at least $40 \%$ in selected regions of the Czech Republic and Slovakia.

H2. Due to the global financial crisis in the Czech Republic and Slovakia, conditions for business of SMEs have been worsened. Average values of a SME performance decrease represent at least $15 \%$.

H3. Due to the deterioration of business environment in the SMEs segment, commercial banks tightened credit conditions. Less than $50 \%$ of entrepreneurs thought, that banks accept their financial needs and behave properly.

H4. Despite the deterioration of business environment, the level of business optimism is high. At least $90 \%$ of entrepreneurs believe that they are able to manage financial risks in their companies properly and that their firms will survey next five years.

The associations in contingency tables were analyzed by Pearson statistics for count data. In the cases, where of asymptotic requirements for the test were violated; series of 5000 Monte Carlo replications from original data has been conducted. P-value is being compared with standard 5\% confidence level. P-value lowers than confidence level leads to rejection of the null hypothesis. The null claims there is no association between variables. Calculations have been performed in statistical packages XL Statistics and R. Tools of descriptive statistics: percentage and averages has been also used.

For better illustration, the Index of change has been calculated ( $\mathrm{I}_{\mathrm{ch}}=$ value of the parameter in the Czech Republic/value of the parameter in Slovakia). Value of the Index of change $\left(I_{c}\right)$ in the interval $(0,0.200)$ demonstrates a zone of low intensity of change. The interval $(0.201,0.500)$ represents moderate intensity change and the interval (0.501, above) constitutes high intensity change of the index. 


\section{RESULTS}

Table 1 shows results of survey of SMEs' business risks in selected regions of the Czech Republic and Slovakia.

Tab. 1 - Identification of business risks in the Czech Republic and Slovakia. Source: own.

\begin{tabular}{|c|c|c|c|}
\hline $\begin{array}{l}\text { You are facing many risks in your job. Which of them do } \\
\text { you consider as the key ones? } \\
\text { Please select maximum of three answers }\end{array}$ & $\begin{array}{l}\text { Czech Republic } \\
2013 \\
\text { in } \% *\end{array}$ & $\begin{array}{l}\text { Slovakia } \\
2013 \\
\text { in } \%\end{array}$ & $\begin{array}{c}\mathrm{p} \text {-value } \\
\mathrm{I}_{\mathrm{ch}}\end{array}$ \\
\hline 1. Market risks (lack of contracts) & 79.44 & 80.49 & 0.9150 \\
\hline Average value ${ }^{* *}$ & 56.00 & 51.30 & 1.092 \\
\hline Adjusted average value*** & 44.49 & 41.29 & 1.077 \\
\hline 2. Financial risk (poor access to financing) & 57.22 & 58.54 & 0.8910 \\
\hline Average value** & 34.00 & 32.95 & 1.032 \\
\hline 3. Operational risk (inability to handle processes) & 20.56 & 22.56 & 0.7480 \\
\hline Average value** & 26.00 & 30.09 & 0.864 \\
\hline 4. Personnel risk (poor staff) & 43.33 & 38.41 & 0.4140 \\
\hline Average value ${ }^{* *}$ & 29.00 & 30.89 & 0.939 \\
\hline 5. Legal risk & 30.56 & 37.20 & 0.2350 \\
\hline Average value $* *$ & 34.00 & 28.76 & 1.182 \\
\hline 6. Security risk (accidents, incidents, etc.) & 21.67 & 32.93 & 0.0260 \\
\hline Average value** & 35.00 & 24.73 & 1.415 \\
\hline
\end{tabular}

Note: *data are calculated as the ratio of number of respondents who reported a given answer to the total number of companies; **average of values reported by entrepreneurs in different regions; ***means the average value of the total data set

The most important business risks which were perceived by entrepreneurs in the Czech Republic and Slovakia were as follows: market, financial and personnel risks. Market risk was identified as a key risk by the largest number of entrepreneurs, that means $79.44 \%$ of them in the Czech Republic and $80.49 \%$ in Slovakia.

Statistically significant differences between regions were not detected excluding security risk.

Average value of market risk which was identified by entrepreneurs in the Czech Republic was $56.00 \%$ and $51.30 \%$ in Slovakia. Amount of adjusted average value (average of whole data set) in the Czech Republic was 44.49\% and $41.29 \%$ in Slovakia.

Table 2 shows how much the performance of SMEs is decreased (according to opinions of entrepreneurs) in 2013 in comparison with the pre-crisis period.

Average performance decrease is represented by $15.80 \%$ in the Czech Republic (weighted average of upper values of individual intervals). Average performance decrease was $18.78 \%$ in Slovakia. 
Test criteria value confirmed that there were no statistically significant differences between two countries.

Tab. 2 - Decrease of SMEs performance in the Czech Republic and Slovakia. Source: own.

\begin{tabular}{|l|c|c|c|}
\hline $\begin{array}{l}\text { By what percentage your current performance has been } \\
\text { decreased compared to the pre-crisis period? }\end{array}$ & $\begin{array}{c}\text { Czech Republic } \\
2013 \\
\text { in } \%\end{array}$ & $\begin{array}{c}\text { Slovakia } \\
2013 \\
\text { in } \%\end{array}$ & p-value \\
\hline 1. up to $10 \%$ & 17.24 & 17.07 & 1.0000 \\
\hline 2. from 11 to $20 \%$ & 13.79 & 20.12 & 0.1590 \\
\hline 3. from 21 to $30 \%$ & 17.24 & 20.73 & 0.4970 \\
\hline 4. from 31 to $40 \%$ & 10.92 & 5.49 & 0.1070 \\
\hline 5. from 41 to 50\% & 5.75 & 6.71 & 0.8890 \\
\hline 6. over 50\% & 3.45 & 6.10 & 0.3730 \\
\hline 7. performance of my company has increased & 31.61 & 23.78 & 0.1380 \\
\hline \multicolumn{2}{|c|}{$\chi^{2}=0.1855$} & & \\
\hline
\end{tabular}

The existence of major business risks determined tighter credit conditions of commercial banks. This trend was perceived also by SMEs which data are shown in Table 3.

Tab. 3 - Banks' access to SMEs financing. Source: own.

\begin{tabular}{|c|c|c|c|}
\hline $\begin{array}{l}\text { How do you assess the banks' access to finance } \\
\text { for SMEs? }\end{array}$ & $\begin{array}{l}\text { Czech Republic } \\
2013 \text { in \% }\end{array}$ & $\begin{array}{l}\text { Slovakia } \\
2013 \text { in } \%\end{array}$ & $\mathrm{p}$-value \\
\hline $\begin{array}{l}\text { 1. banks fully accept our needs and } \\
\text { support us }\end{array}$ & 4.44 & 3.05 & 0.6930 \\
\hline 2. banks behave appropriately & 38.89 & 20.12 & $<0.01$ \\
\hline $\begin{array}{l}\text { 3. banks behave to us with some reser- } \\
\text { vations }\end{array}$ & 8.89 & 14.02 & 0.1830 \\
\hline $\begin{array}{l}\text { 4. banks use too harsh criteria when } \\
\text { provide loans }\end{array}$ & 26.11 & 37.20 & 0.0360 \\
\hline 5. I cannot evaluate & 21.67 & 25.61 & 0.4630 \\
\hline \multicolumn{4}{|c|}{$\chi^{2}=16.453$, p-value $<0.01$} \\
\hline
\end{tabular}

Our research confirmed the fact that there are differences between opinions of entrepreneurs in the Czech Republic and Slovakia. Entrepreneurs in the Czech Republic are more convinced that banks behave appropriately than entrepreneurs in Slovakia who are more convinced that banks use too harsh criteria. It can be applied in both countries that the portion of ,satisfied one" (line 1+2) is lower than 50\% (p-value is 0.0430 for the Czech Republic and for Slovakia is p-value less than 0.01). 
Ability to manage financial risks has been verified through following questions. Results are shown in Table 4.

Tab. 4 - Ability to manage financial risks in the company. Source: own.

\begin{tabular}{|l|c|c|c|}
\hline $\begin{array}{l}\text { Do you think that you can manage financial risks in } \\
\text { the company properly? }\end{array}$ & $\begin{array}{c}\text { Czech Republic } \\
2013 \text { in } \%\end{array}$ & $\begin{array}{c}\text { Slovakia } \\
2013 \text { in \% }\end{array}$ & p -value \\
\hline 1. yes & 41.11 & 23.17 & $<0.01$ \\
\hline 2. to the certain extent & 55.00 & 67.68 & 0.0210 \\
\hline 3. no & 0.56 & 1.83 & - \\
\hline 4. I cannot judge & 3.33 & 7.32 & - \\
\hline \multicolumn{2}{|r|}{$\chi^{2}=$ due to small number in the line 3 and 4, this value cannot be calculated reliably } \\
\hline
\end{tabular}

Entrepreneurs in our research presented the opinion that they can manage financial risks in their companies. Czech entrepreneurs definitely thought that they can manage financial risks properly compared with Slovak businessmen.

Point estimate of the proportion of Czech entrepreneurs who believe that they can manage financial risks properly (line 1+2) is $96.11 \%$ and $90.85 \%$ in Slovakia.

Using hypothesis testing for a proportion, null hypothesis was rejected in favor of the alternative hypothesis ( $\mathrm{p}$-value is less than 0.01) for Czech entrepreneurs. It can be stated that the portion of Czech companies which thought that they can manage financial risks properly, is more than $90 \%$. This argument cannot be confirmed in the case of Slovak companies. (p-value is 0.407)

The level of business optimism has been obtained through following questions. Results are shown in Table 5

Tab. 5 - The level of business optimism. Source: own.

\begin{tabular}{|l|c|c|c|}
\hline $\begin{array}{l}\text { Do you believe that you firm will survive in } \\
\text { next five years? }\end{array}$ & $\begin{array}{c}\text { Czech Republic 2013 } \\
\text { in \% }\end{array}$ & $\begin{array}{c}\text { Slovakia 2013 } \\
\text { in \% }\end{array}$ & p -value \\
\hline 1.absolutely & 49.44 & 40.85 & 0.1360 \\
\hline 2. no & 0.56 & 2.44 & 0.3140 \\
\hline 3. with some concerns & 45.56 & 49.39 & 0.5430 \\
\hline 4. with great concerns & 4.44 & 7.32 & - \\
\hline \multicolumn{2}{|r|}{$\chi^{2}=4.9753, p$-value $=0.1784$} \\
\hline
\end{tabular}

Entrepreneurs in our research showed large dose of business optimism. In the Czech Republic, up to $95 \%$ of entrepreneurs stated that they believed that their company will survive in next five years in surveyed research. This share was represented by $90 \%$ in Slovakia. The level of business optimism in the Czech Republic and Slovakia is very similar.

Using testing for a proportion ( $\mathrm{p}$-value is 0.0174 ), the null hypothesis was rejected for Czech companies where it stated that portion of optimistic firms is higher than $90 \%$. In the case of 
Slovakia, the null hypothesis is not rejected ( $\mathrm{p}$-value is 0.5 ) and therefore it cannot be stated that portion of optimistic companies in Slovakia is higher than $90 \%$.

\section{DISCUSSION}

Small and medium enterprises have an irreplaceable contribution for economic growth, employment and competitiveness of each country but because of their size, they are sensitive to changes within external environment. Their productivity is disturbed by the existence of barriers in business. In the term of functioning of market mechanism it is correct when the market is able to regulate itself without any state interference. According to Čihovská \& Nekolová (2012), small and medium enterprises are unable to maintain a control over a market in which they operate. SMEs are sensitive to changes in the business environment, and therefore they take higher business risks.

In longer term period, discussion about SMEs problems is focused on issue of levies, quality of legal system and support of SME by state. Our research confirmed that there are currently other priorities in the business environment and entrepreneurs intensively perceive influence of market risks. In this context, it is important to create systematic conditions for the growth of consumer optimism in the economy.

It is interesting that politicians and experts intensively discuss about position of SMEs. But a real business practice confirms that there has not been changed practically anything for a long period of time. Entrepreneurs evaluate that the access of the state to them is extremely negative, because $84 \%$ of entrepreneurs in the Czech Republic had a feeling that the state is just bullied them or is not fulfill its task. Only $3 \%$ of companies said that the state helps them in business. In Slovakia, $53 \%$ of entrepreneurs thought that the state bullied them, $38 \%$ of companies thought that the state does not fulfill their obligations and only $5 \%$ of entrepreneurs thought that the state fulfills its duties.

It is important for economic growth of country that the status of entrepreneurs is correctly perceived by the company. According to results of our research, only $8 \%$ of entrepreneurs in the Czech Republic thought that their company perceives correctly but up to $63 \%$ of them thought that their company perceives incorrectly and negatively. In Slovakia only $7 \%$ of companies thought that they perceive correctly, $16 \%$ of them thought that their company perceives negatively and $43 \%$ of companies thought that their company perceives incorrectly.

Public opinion pulling which was conducted by Republican Union of Employers and Business of Slovakia points to the fact that the perception of entrepreneurs and entrepreneurship in Slovakia is bad. These surveys showed that $75 \%$ of adult population thinks that entrepreneurs strive for quick profit, get rich at the expense of ordinary people and inappropriately exploited their employees.

For optimal functioning of the economic system, optimism of its participants is very important. In this context there is favorable news that dominant part of Czech and Slovak entrepreneurs believe that their company will survive in next five years despite significant changes in business environment which brought significant decline in the performance of companies and their profitability. 


\section{CONCLUSION}

In our research the hypothesis no.1 has been confirmed. Nowadays, the most important business risk of SMEs represents the market risk. According to opinions of Czech and Slovak entrepreneurs, average value of market risks was less than $40 \%$ in selected regions of the Czech Republic and Slovakia.

Hypothesis no.2 has been also confirmed. Due to global financial crisis of SMEs in the Czech Republic and Slovakia, conditions for SMEs business have worsened. The average value of SMEs performance decrease represents 15.80\% in the Czech republic and 18.78\% in Slovakia.

Hypothesis no. 3 has been confirmed. Due to deterioration in the business environment of SMEs segment, commercial banks tightened credit conditions. Less than $50 \%$ of entrepreneurs in the Czech Republic and Slovakia thought that banks accept their needs of behave appropriately.

Hypothesis no. 4 was also confirmed in Czech business environment where at least $90 \%$ of entrepreneurs believe that they are able to manage financial risks properly in their companies and their companies will survive in next five years. In Slovakia, the validity of this hypothesis was not confirmed.

On the basis of our research, it can be argued that entrepreneurs in Zlin region declared better conditions for their business compared to Žilina region. These entrepreneurs slightly less intensively perceived market and financial risk compared to entrepreneurs from Žilina regions, and less intensively perceived impacts of the crisis on their financial performance, declared high level of the competitiveness in the area of financial risk management and also higher level of business optimism.

\section{Acknowledgement:}

This paper was supported by Project No. FaME/2013/MSPRISK: Current trends in the area of business risks of small and medium enterprises in selected regions of the Czech Republic and Slovakia.

This paper was created at the Tomas Bata University in Zlin and was supported by Project No. IGA/ FaME/2013/010: Satisfaction mirror effect and bank financial performance.

\section{References}

1. Avlonitis, G. J., \& Salavou, H. E. (2007). Entrepreuneurial orientation of SMEs, product innovativeness, and performance. Journal of Business Research, 60(5), 566-575.

2. Canales, R., \& Nanda, R. (2012). A darker side to decentralized banks: Market power and credit rationing in SME lending. Journal of Financial Economics, 105(2), 353-366. http://dx.doi. org/10.1016/j.jfineco.2012.03.006

3. Čihovská, M., \& Nekolová, I. (2012). Možnosti a bariéry vstupu malých a stredných podnikov SR na jednotný trh EÚ (Výsledky marketingového prieskumu). Medzinárodné vat'aby, 10(2), 43-55.

4. Dierkes, M., Erner, C., Langer, T., \& Norden, L. (2013). Business credit information sharing and default risk of private firms. Journal of Banking \& Finance 37(8), 2867- 2878. http://dx.doi.org/10.1016/j.jbankfin.2013.03.018

5. Di Giuli, A., Caselli, S., \& Gatti, S. (2011). Are small family firms financially sophisticated? Journal of Banking \& Finance, 35(11), 2931-2944. http://dx.doi.org/10.1016/ j.jbankfin.2011.03.021 
6. Eggers, F., Kraus, S., Hughes, M., Laraway, E., \& Snycerski, S. (2013). Implications of customer and entrepreneurial orientations for SME growth. Management Decision, 51(3), 524546. http://dx.doi.org/10.1108/00251741311309643

7. Evropská komise. (2011). Velké zámèry pro malé podniky - co dělá EU pro MSP. Lucemburk: Úřad pro publikace EU.

8. Európska komisia. (2006). Ako sa vyrovat's novou ratingovou kultúrou. Brusel: Európska komisia.

9. Fetisovová, E., Vlachynský, K., \& Sirotka, V. (2004). Financie malých a stredných podnikov. Bratislava: Ekonómia.

10. Gerši, A., \& Jakubík, P. Modely bankovního financování českých podniků a úvérové riziłko. Retrieved from http://is.vsfs.cz/el/6410/zima2012/N_RRFS/FS_2008-2009_clanek_3.pdf

11. Henderson, J., \& Weiler, S. (2010). Entrepreneurs and job growth: probing the boundaries of time and space, Economic Development Quarterly, 24(1), 23-32. http://dx.doi.org/10.1177/08 91242409350917

12. Karpak, B., \& Topcu, I. (2010). Small medium manufacturing enterprices in Turkey: an analytic network process framework for prioritizing factors affecting success. International Journal of Production Economics, 125(1), 60-70. http://dx.doi.org/10.1016/j.ijpe.2010.01.001

13. Keh, H. T., Nguyen, T. T. M., \& Ng, H. P. (2007). The effect of entrepreneurial orientation and marketing information on the performance of SMEs. Journal of Business Venturing, 22(4), 592-611. http://dx.doi.org/10.1016/j.jbusvent.2006.05.003

14. Kirschenbaum, K., \& Norden, L. (2012). The Relationship between Borrower Risk and Loan Maturity in Small Business Lending. Journal of Business Finance \& Accounting, 39(5-6), 730-757. http://dx.doi.org/10.1111/j.1468-5957.2012.02285.x

15. Krištofík, P. (2010). Poučenia z krízového vývoja. Retrieved January 6, 2010, from http://www. financnymanazment.sk/2010-1/6-2010/Poucenia-z-krizoveho-vyvoja/

16. Májková-Sobeková, M. (2011). Analýza bariér a faktorov financovania malých a stredných podnikov v SR. Ekonomický časopis, 59(10), 1033 - 1046.

17. Moro, A., \& Fink, M. (2013). Loan managers'trust and credit access for SMEs. Journal of Banking \& Finance, 37(3), 927-936. http://dx.doi.org/10.1016/j.jbankfin.2012.10.023

18. Pavelková, D., \& Knápková, A. (2005). Výkonnost podniku zpobledu finančního manažera. Praha: Linde.

19. Polách, J., Drábek, J., Merková, M., \& Polách, J. (2012). Reálné a finanční investice. Praha: C.H.Beck.

20. Riziká podnikania. (2013). Hlavné nevýhody a rizikáá podnikania. Retrieved from http:// msponline.sk/content/hlavne-nevyhody-rizika-podnikania

21. Nueberger, D., \& Räthke, S. (2009). Microenterprises and multiple relationships: The case of professionals. Small Business Economics, 32(2), 207-229. http://dx.doi.org/10.1007/s11187007-9076-8 
22. Soininen, J., Martikainen, M., Puumalainen, K., \& Kyläheiko, K. (2012). Entrepreneurial orientation: Growth and profitability of Finnisch small- and medium-sized enterprises. International Journal of Production Economics, 140(2), 614-621. http://dx.doi.org/10.1016/ j.ijpe.2011.05.029

\section{Contact information}

assoc. prof. Ing. Jaroslav Belás, PhD.

Department of Enterprise Economics

Faculty of Management and Economics

Tomas Bata University in Zlin

Mostni 5139, 76001 Zlin

Email: belas111@gmail.com

Ing. Jirú Macháčele.

Faculty of Management and Economics

Tomas Bata University in Zlin

Mostni 5139, 76001 Zlin

Email:machacek@fame.utb.cz.

Ing. Premysl Bartoš

Faculty of Management and Economics

Tomas Bata University in Zlin

Mostni 5139, 76001 Zlin

Email:bartos@fame.utb.cz.

Ing. Roman Hlawiczka

Faculty of Management and Economics

Tomas Bata University in Zlin

Mostni 5139, 76001 Zlin

Email: blawiczka@fame.utb.cz.

Ing. Mária Hudáková, PhD.

Faculty of Special Engineering

University of Zilina

Ul. 1. mája 32, 01026 Žilina

Email:Maria.Hudakova@fsi.uniza.sk 